\title{
FACTORS INFLUENCING SUSHI MEAL AS REPRESENTATIVE OF NON-TRADITIONAL MEAL: CONSUMPTION AMONG CZECH CONSUMERS
}

\author{
Đ. ĐORĐEVIĆ* and H. BuchtovÁ
}

Department of Meat Hygiene and Technology, Faculty of Veterinary Hygiene and Ecology, University
of Veterinary and Pharmaceutical Sciences Brno, Palackého tř. 1946/1, 61242 Brno. Czech Republic

(Received: 4 June 2016; accepted: 29 August 2016)

\begin{abstract}
Determination of consumers' acceptance level of sushi meal among Czech respondents was the main aim. The survey included 1352 respondents that filled in a questionnaire on their demographic characteristics and food preferences regarding their acceptance of sushi meal. Additionally, 79 volunteers participated in sorting sushi among other 14 popular meals in the Czech Republic, according to their assumed situations. The results indicate that sushi is highly accepted among Czech consumers (more than $80 \%$ of respondents consume sushi) due to sensory characteristics and health benefit claims of sushi. The main barrier for sushi acceptance is sushi being a cold meal. The study emphasized that sushi price highly influences not only consumption frequency but also acceptance of sushi among respondents who declared not consuming this type of meal.
\end{abstract}

Keywords: sushi, acceptance, Czech Republic, food preferences, price

The Czech Republic does not belong to states with high fish consumption per capita (in total $3.7 \mathrm{~kg}$, out of which $1.3 \mathrm{~kg}$ is freshwater fish). The estimation is that $40 \%$ of citizens consume fish more than once per week (1 kg per capita per year) (PIENIAK et al., 2013; Ministry OF Agriculture, 2015). Sushi meal popularity can be seen as a potential way of fish consumption increase. Some of the reasons for sushi's worldwide popularity are its diversity and colourfulness. Sushi diversity probably is one of the main reasons for the global popularity of sushi.

Since 1970, sushi is also consumed in countries where it was not present earlier. Greater expansion of sushi restaurants in Europe and America occurred in the 1990s. The capability to adjust to different cultures certainly induces sushi bar expansions (CZARNIECKA-SKUBINA \& NowAK, 2014).

Sushi consumption prevalence among adult population measured in some European countries amounted to $50 \%$ in Poland, $40 \%$ in France, and 30\% in Norway (CZARNIECKASkUBINA \& NowAK, 2014; Hoel et al., 2015). Some statements are pointing to that the reason for sushi popularity lies in global rise of health consciousness, sorting sushi meal to healthy meal choice, in spite of certain level of ethnocentrism that is present in each country (ORTH \& Firbasova, 2002; Cysneiros et al., 2009).

The price of sushi meals in worldwide restaurants is somehow opposite from assumptions: sushi was "invented" in the period of food shortages and famine, it belongs to fast food cuisine, and fast food restaurants are usually connected with lower income people (DONLEY, 1995; Krauss \& Nyblade, 2004; De Silva \& Yamao, 2006; Kim \& Leigh, 2011). On the other

* To whom correspondence should be addressed.

E-mail: dani_dordevic@yahoo.com 
side, sushi meal is very often perceived as some kind of glamour and prestige (SAKAмOTO \& Allen, 2011).

The aim of the research was to analyse how sushi meal is accepted among Czech consumers, reviewing an impact of demographic characteristics on their food preferences and to compare food choices/attitudes between respondents consuming and not consuming sushi.

\section{Materials and methods}

The questionnaires were carried out both in-person (mainly at the Veterinary and Pharmaceutical University in Brno, Czech Republic) and online (written in Czech language with the usage of Google forms/docs). The research group consisted of 1352 respondents. The study was conducted between May 2015 and October 2015. The questionnaire counted 36 questions, consisting of two parts. The first part $(n=6)$ was about demographic characteristics of respondents (Table 1); the second part depended on respondent's sushi meal acceptance. More females $(81.9 \% ; n=1107)$ than males $(18.1 \% ; n=245)$ participated in the survey, and most of them were not married $(82.2 \% ; n=1101)$.

Table 1. Demographic information about respondents $(100 \% ; \mathrm{n}=1352)$

\begin{tabular}{|c|c|c|c|}
\hline $\begin{array}{l}\text { Demographic } \\
\text { category }\end{array}$ & Groups & Number of respondents & $\begin{array}{l}\text { Percentage of } \\
\text { respondents }\end{array}$ \\
\hline \multirow[t]{2}{*}{ Gender } & Female & 1107 & 81.9 \\
\hline & Male & 245 & 18.1 \\
\hline \multirow[t]{2}{*}{ Marital status } & Married & 239 & 17.8 \\
\hline & Not married & 1101 & 82.2 \\
\hline \multirow[t]{5}{*}{ Age } & Under 20 years & 250 & 18.5 \\
\hline & $21-30$ years & 822 & 60.8 \\
\hline & $31-40$ years & 121 & 8.9 \\
\hline & $41-60$ years & 47 & 3.5 \\
\hline & Over 60 years & 112 & 8.3 \\
\hline \multirow[t]{3}{*}{ Education level } & Elementary school & 91 & 6.8 \\
\hline & Secondary school & 818 & 60.8 \\
\hline & Higher education & 436 & 32.4 \\
\hline \multirow[t]{6}{*}{ Current status } & Student & 738 & 54.7 \\
\hline & An employee of state & 116 & 8.6 \\
\hline & Private employee & 268 & 19.9 \\
\hline & SEP (self-employed people) & 74 & 5.5 \\
\hline & Unemployed & 45 & 3.3 \\
\hline & Retired & 108 & 8 \\
\hline \multirow[t]{3}{*}{ Income group* } & Below average (<550 EUR) & 914 & 70.9 \\
\hline & Average (550 EUR-1100 EUR) & 303 & 23.5 \\
\hline & Above average ( $>1100$ EUR) & 73 & 5.7 \\
\hline
\end{tabular}

*: time period: monthly/person 
The survey also included sushi meal perception of 79 volunteers (V) (students at the University of Veterinary and Pharmaceutical Sciences Brno, 20-30 ages old). They positioned sushi meal among 14 other meals (roast pork with dumplings and sauerkraut, beef sirloin in cream sauce, fried carp with potato salad, beef goulash, duck with cabbage and potato salad, fried cheese with ham, steak tartar with toast, green salad with tuna and eggs, pizza, dumplings filled with fruit, sandwiches with ham, McDonald menu, pork gyros with noodles, Spanish roll with rice) according to different consumer situations (with or without financial limits, choosing the healthiest meal and choosing the most satiety meal). The selection of 14 meals was based on conducted researches (electronic sources) in the Czech Republic (CzECH Academy of Sciences, 2003; Budinska, 2012; Hamerska, 2013).

The statistical analysis was performed using SPSS 20 statistical software (IBM Corporation, Armonk, USA). The comparison of data was based on $t$-test and one-way ANOVA analysis with post-hoc Tukey's test for finding differences within more than two variances. Additional information about the association of variables was provided by chisquared tests. Non-parametric Friedman's test (with application of Wilcoxon signed-rank test and Bonferroni correction) was applied for finding differences between preferences of $\mathrm{V}$ group respondents.

\section{Results and discussion}

\subsection{Sushi consumption habits and frequencies}

More than $80 \%(n=1088)$ of respondents stated that they consume sushi, while $19.5 \%(n=263)$ answered that they have never tasted sushi meal. Sushi meal acceptance among respondents was considerably higher than in some other European states (CZARNIECKA-SKUBINA \& NowAK, 2014; HoEl et al., 2015).

Sushi acceptance depended (chi-square test; $\mathrm{P}<0.05$ ) on respondents' age, education level (the highest consumption among age group 21-30 years with higher education), and respondents' occupation (students accepted sushi more: 57.9\%; more respondents in retirement do not consume sushi: $26.8 \%$ ). The survey investigating ethnocentrism among the Czech population showed that younger respondents with higher education are easier to accept foreign products, and they are less likely to be ethnocentric (ORTH \& FIRBASOVA, 2002). In our study, ethnocentrism is noticeable among NCS group, represented with respondents' answer that they consume only Czech cuisine $(20.9 \%$; $n=53)$. The main reasons for respondents' sushi consumption are shown in Figure 1. It can be seen that beside tastiness $(88.3 \%$; $n=954)$ and health attributes $(38.9 \% ; n=420)$, curiosity $(21.3 \% ; n=230)$ also is an important factor in sushi acceptance. Connections between sushi consumption and curiosity can also be overviewed through the higher consumption of not traditional meat types (sheep, goats, horse) among sushi consumers in comparison $(\mathrm{P}<0.05)$ with NCS respondents. Curiosity of consumers is often leads them to consume not familiar products for which they are often willing to pay a higher price (D’Amico et al., 2016).

The majority of respondents consume sushi only in rare instances $(43.3 \% ; n=468)$, but not negligible number of respondents consume sushi once per month $(26.1 \% ; n=281)$ (Fig. 2), which is much more than in Poland (10\%) (CZARNIECKA-SKUBINA \& NowAK, 2014), though less than in Japan (29\%) (De Silva \& YamaO, 2006). The frequency of visiting sushi bars depended $(\mathrm{P}<0.05)$ on respondents' age, occupation, income (respondents under 40 years, not in retirement, and with above average monthly income consumed sushi more frequently), and respondents' favourite sushi types. Respondents whose favourite sushi types are maki and 
nigiri (Fig. 3) (maki: seafood and other ingredients rolled in vinegared rice with nori seaweed on outside; nigiri: seafood slice pressed over ball size of vinegared rice) consumed sushi more frequently $(\mathrm{P}<0.01)$, while respondents who stated that they do not differentiate between sushi types consumed sushi less frequently $(\mathrm{P}<0.01)$. Respondents' favourite seafood included in sushi meal is shown in Figure 4. In Japan the most popular fish used for sushi preparation is tuna (De Silva \& YAMAo, 2006).

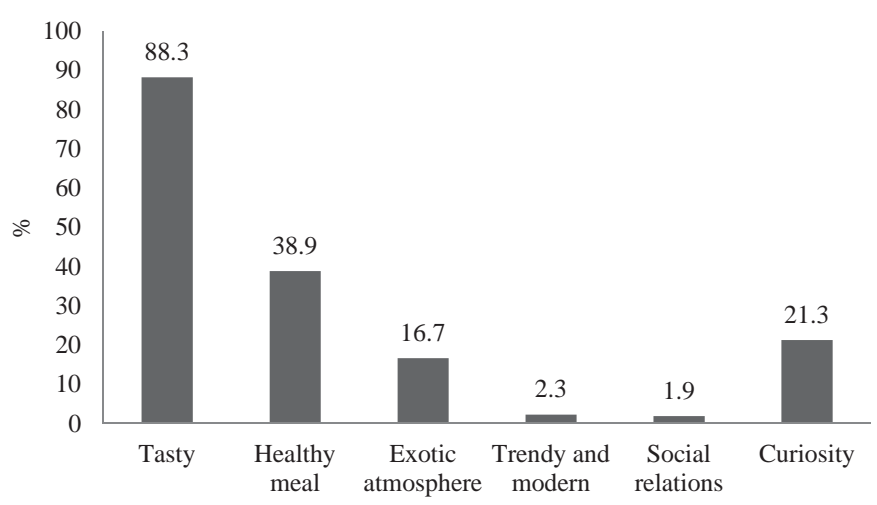

Fig. 1. Respondents' ( $\mathrm{n}=1088)$ reasons for consuming sushi meal

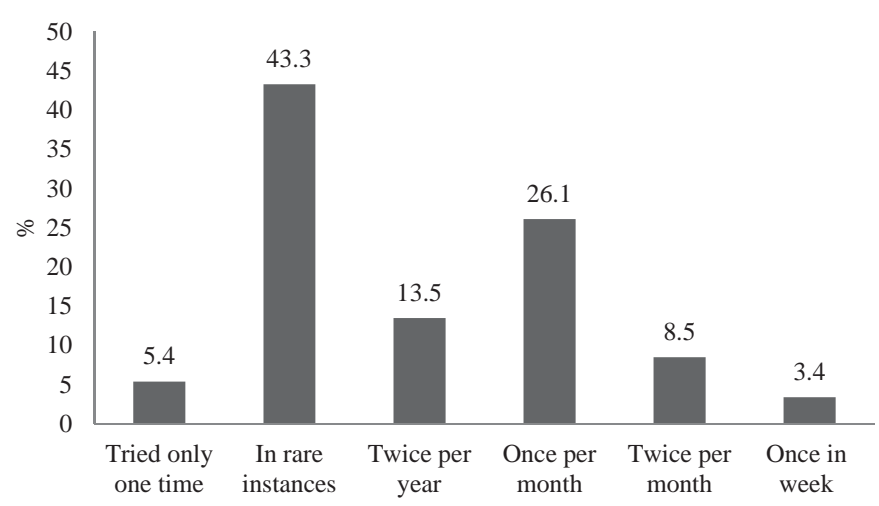

Fig. 2. Respondents' ( $\mathrm{n}=1088)$ frequency of consuming sushi

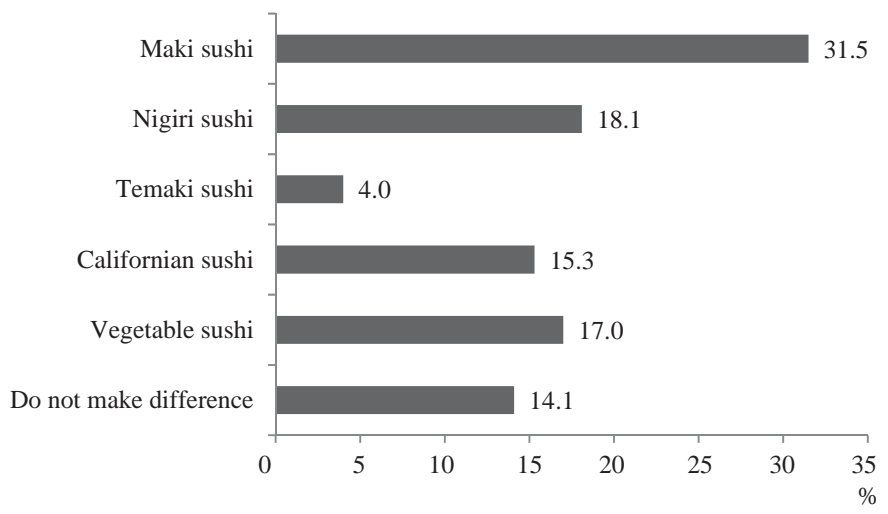

Fig. 3. Respondents' (n=1088) favourite sushi types among respondents 


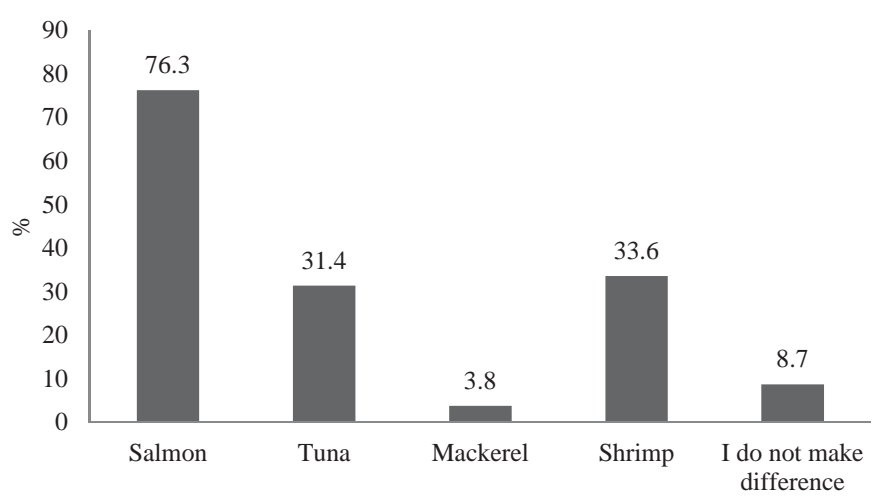

Fig. 4. Respondents' (n=1088) favourite seafood included in sushi meal

\subsection{Sushi meal among other meals}

The perception of respondents toward sushi meal, when they have to choose meals according to taste, price, health benefits, and satiety, was evaluated by analysing $\mathrm{V}$ group. $\mathrm{V}$ group placed sushi meal at the first place $(\mathrm{P}<0.05)$ (among 14 other meals) when they were instructed to sort meals only according to taste, and at the second place (statistical significance was observed between sushi and other selected meals; $\mathrm{P}<0.05$ ) according to health benefits. Though, by Friedman's test, statistical significance was not found between preferences of V group respondents, when they chose meals according to taste, price, health benefits, and satiety. According to V group, sushi was at the bottom of scale $(\mathrm{P}<0.05)$ describing volunteers' perceptions how offered meals would make them reach satiety. More familiar/traditional meals were perceived as more sating by respondents (BuCKLAND et al., 2015). The tastiness of meal is the most important meal attribute for Czech consumers according to results obtained by questioning $\mathrm{V}$ group, where respondents arranged their personal priorities in meal choosing in the following order: taste $43.98 \%$; healthiness $30.84 \%$; price $27.30 \%$. The majority of respondents in $\mathrm{V}$ group consumed sushi only in rare instances $(73.4 \% ; \mathrm{n}=58)$ and only $(6.3 \% ; n=5)$ consumed it once per month.

\subsection{Health attributes of sushi meal}

Greater amount of healthy fats $(57.2 \%$; $=588)$ and omega-3 polyunsaturated fatty acids (PUFAn-3) $(39.3 \%$; $n=404)$ were the main reasons for sushi to be considered a healthy meal (Fig. 5). People like sushi, because it contains low amount of calories (8-10 pieces of sushi $=350-450$ calories), and it is considered nutrient concentrated meal (CysNEIROS et al., 2009).

Raw seafood inclusion in sushi meal leads to higher protein and lipid bioaccessibility in comparison with cooked seafood (due to covalent bonds formed between polypeptide chains among amino acids) (MATsu et al., 2013). It was calculated that 5 pieces of sushi, which include $20 \mathrm{~g}$ of fatty seawater fish, satisfy the daily requirements for vitamin $\mathrm{B}_{6}$ (Huong \& Toshinaru, 2012). Other ingredients of sushi, such as seaweeds, ginger, and wasabi, are also good sources of vitamins and minerals. Ginger and wasabi have antibacterial properties and help to strengthen the immune system. Wasabi is a good source of vitamin C (De SiLva \& YAMAO, 2006; Cysneiros et al., 2009). 


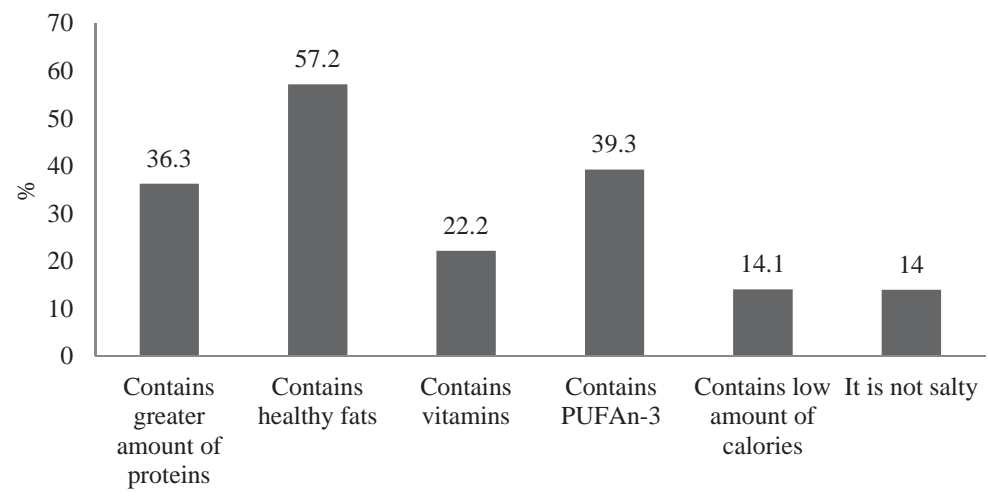

Fig. 5. Respondents' $(\mathrm{n}=1088)$ comprehension about health benefits of sushi meal

Seafood portion in sushi is an adequate according to $50.2 \%(\mathrm{n}=532)$ respondents, while $14.1 \%(\mathrm{n}=149)$ thought that it is small. According to ADAMS and co-workers (1990), an average weight of salmon slice used for sushi preparation was $11.1 \mathrm{~g}$ with mean thickness of $0.7 \mathrm{~cm}$.

\subsection{Reasons for avoidance of sushi meal}

The main reasons for not consuming sushi were that respondents are not used to consume cold meals $(41.3 \%$; $\mathrm{n}=100)$, they consider sushi meal too exotic $(32.2 \%$; $\mathrm{n}=78)$, personal financial situation $(29 \% ; \mathrm{n}=76)$, and too expensive meal $(27.3 \%$; $\mathrm{n}=66)$. In the Czech Republic people prefer hot meal for lunch as major meal. The majority of people have at least one hot meal per day (MAKelA et al., 1999).

Other reasons for not consuming sushi were that $60.5 \%(\mathrm{n}=144)$ respondents did not consume raw meat including fish, $11.3 \%(\mathrm{n}=27)$ did not consume fish, and $1.3 \%(\mathrm{n}=3)$ did not consume rice. Vegetarianism was also, according to respondents (belonging to NCS group), one of the main reason for avoidance of sushi meal $(11.8 \% ; \mathrm{n}=28)$, though vegetarian sushi is offered in restaurants. Respondents from NCS group declared $(55.8 \% ; \mathrm{n}=63)$ that near their residence there is no sushi restaurant.

CS respondents prefer $(\mathrm{P}<0.05)$ more cold salty meals $(11.58 \% ; \mathrm{n}=123)$ in comparison with NCS group $(2.8 \% ; n=7)$. Differences in respondents' preferences toward favourite meat types can be seen in Figure 6. Respondents from CS group preferred more $(\mathrm{P}<0.05)$ seafood $(14.09 \% ; n=103)$, sea fish $(20.38 \% ; n=149)$, and freshwater fish $(9.58 \% ; n=70)$.

\subsection{Sushi price}

The majority of respondents $(63.4 \%$; $n=675)$ perceived sushi meal price as adequate for this type of meal and its exotic characteristics; oppositely to sushi history (Donley, 1995; Krauss \& Nyblade, 2004; De Silva \& Yamao, 2006; Kim \& Leigh, 2011). Greater number of respondents connected economical issues with more frequent visits to sushi bars (if they have more money: $42.4 \% \mathrm{n}=641$; if sushi meal is cheaper: $30.6 \% \mathrm{n}=464)$. Respondents' consideration toward sushi meal price depended $(\mathrm{P}<0.05)$ on their monthly income, bigger portion of respondents belonging to below average income had opinion that it is costly. 
$\mathrm{V}$ group confirmed that sushi meal belongs to expensive meals $(\mathrm{P}<0.05)$. Among sushi consumers there is a well-accepted assumption that sushi meal is not a cheap meal, but it is very often perceived as some kind of glamour and prestige (Donley, 1995; SAKamoto \& AlLen, 2011).

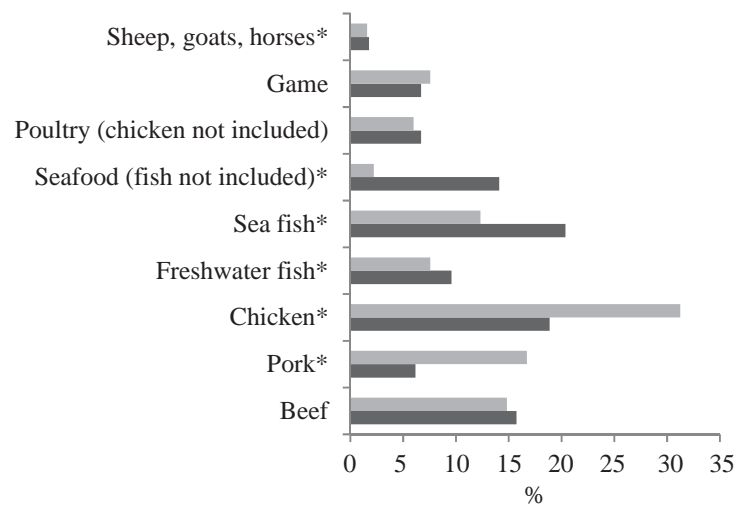

Fig. 6. Favourite meat type preferences of respondents who consume $(\mathrm{n}=1088)$ and do not consume sushi $(\mathrm{n}=263)$ $* t$-test, statistical significant difference $(\mathrm{P}<0.05)$ between two respondents groups ㅍ: Not consuming sushi; $\mathbf{m}:$ Consuming sushi

ADAMS and co-workers (1990) made the calculation that an average salmon fish fillet weighs $2.27 \mathrm{~kg}$, and that one salmon fish can provide 1000 maki sushi salmon pieces. The average price of $1 \mathrm{~kg}$ of salmon is around 6 Euros, meaning that the value of salmon included in one piece of sushi is around 0.014 Euros (FRANK \& BJORNDAL, 2011).

\section{Conclusions}

The research found high acceptance of sushi meal among respondents, which can be seen as possible chance for seafood intake increment among Czech consumers. Information consumers have on non-traditional meal seemed to be important, and it certainly highly influences acceptance and especially the frequency of meal consumption. According to the survey, not negligible number of respondents thought that sushi meal cannot be vegetarian, and also many respondents cannot differentiate between sushi types representing the lack of information/knowledge about this meal. Czech consumers' preferences are eminently influenced by meal characteristics, which can induce their curiosity, as shown in the research. The survey can serve as stimulus for further consumers' preferences investigation about nontraditional meal and be used for comparison, since this kind of research has never been done in the Czech Republic. 


\section{References}

Adams, A.A., Beeh, J.L. \& Wekell, M.M. (1990): Health risks of salmon sushi. Lancet, 24, 1328.

Buckland, N.J., Stubbs, R.J. \& Finlayson, G. (2015): Towards a satiety map of common foods: associations between perceived satiety value of 100 foods and their objective and subjective attributes. Physiol. Behav., $152,340-346$.

BudinsKa, E. (2012). 10 nejtypičtějšich českých jídel (10 typical Czech meals). Available at http://easymagazine.cz/ clanky/10-nejtypictejsich-ceskych-jdel (last accessed 25 August 2016)

Cysneiros, R.M., Arida, R.M., Terra, V.C., Sonoda, E.Y., Cavalheiro, E.A. \& Scorza, F.A. (2009): To sushi or not to sushi: Can people with epilepsy have sushi from time to time? Epilepsy Behav., 16, 565-566.

Czarniecka-Skubina, E. \& Nowak, D. (2014): Japanese cuisine in Poland: attitudes and behavior among Polish consumers. Int. J. Consum. Stud., 38, 62-68.

Czech Academy of Sciences. (2003): Stravovací zvyky Čechů (Eating habits of Czechs). Available at http://cvvm. soc.cas.cz/media/com_form2content/documents/c1/a2989/f3/100258s_or30825.pdf (last accessed 25 August 2016)

D’Amico, M., Di Vita, G. \& Monaco, L. (2016): Exploring environmental consciousness and consumer preferences for organic wines without sulfites. J. Clean. Prod., 120, 64-71.

De Silva, D. \& Y Amao, M. (2006): A yen for sushi: an analysis of demographic and behavioural patterns of sushi consumption in Japan. J. Foodservice, 17, 63-76.

Donley, R. (1995): Everything has its price. Simon \&Schuster, New York, (Chapter 4.), pp. 18-24.

Frank, A. \& Bjorndal, T. (2011): The economics of salmon aquaculture. $2^{\text {nd }}$ ed. Wiley-Blackwell, Chichester, West Sussex. pp. 1-7.

Hamerska, J. (2013): Fast food versus slow food. Thesis. Masaryk University, Brno, Czech Republic. Available at http://is.muni.cz/th/323462/lf_m/DP_Fast_food_versus_slow_food.pdf (last accessed 25 August 2016)

Hoel, S., Mehl, L., Bruheim, T., Vadstein, O. \& Jakobsen, A.N. (2015): Assessment of microbiological quality of retail fresh sushi from selected sources in Norway. J. Food Protect., 78, 977-982.

Huong, T.V.D. \& Toshinaru, Y. (2012): Individual vitamin B $_{6}$ contents in selected Japanese sushi toppings. Int. J. Food Sci. Nutr., 63, 246-249.

Kim, D. \& Leigh, J.P. (2011): Are meals at full-service and fast-food restaurants "normal" or "inferior"? Popul. Health Manag., 14, 307-315.

Krauss, E.S. \& Nyblade, B. (2004): Japan and North America. Routledge Curzon Library of Modern Japan. RoutledgeCurzon, London. pp. 417-435.

Makela, J., Kuaernes, U., Ekstrom, M.P., Furst, E.L., Gronow, J. \& Holm, L. (1999): Nordic meals: Methodological notes on a comparative survey. Appetite, 32, 73-79.

Matsui, H., Tsuchiya, R., Isobe, Y. \& Narita, M. (2013): Analysis of bacterial community structure in saba-narezushi (narezushi of mackerel) by 16S rRNA gene clone library. J. Food Sci. Tech., 50, 791-796.

Ministry of Agriculture. (2015): Situačni a výhledová zpráva ryby (Situation and outlook report on fish. Czech Republic-Ministry of Agriculture, Department of State forest governance, hunting and fishing (November 2015)). Prague, Czech Republic, pp. 3-32.

Orth, U.R. \& Firbasova, Z. (2002): Ethnocentrism and consumer evaluations of Czech made yoghurt. Agr. Econ. - Czech, 48, 175-181.

Pieniak, Z., Vanhonacker, F. \& Verbeke, W. (2013): Consumer knowledge and use of information about fish aquaculture. Food Policy, 40, 25-30.

Sakamoto, R. \& Allen, M. (2011): There's something fishy about that sushi: how Japan interprets the global sushi boom. Japan Forum, 23, 99-121. 